\title{
Evolution of Neurosurgery in Bangladesh
}

\author{
Khan $\mathrm{AH}^{1}$, Hossain $\mathrm{ATMM}^{2}$, Shalike $\mathrm{N}^{3}$, Barua $\mathrm{KK}^{4}$
}

\begin{abstract}
:
The beginning of Neurosurgery is not very new in Bangladesh. Prof.Rashiduddin Ahmed established the first Neurosurgery unit in the then Institute of Postgraduate Medical Research (IPGMR) with only six beds in 1970. The first generation neurosurgeons left the field of neurosurgery in the safe hands of their disciples. There was a rapid progression of neurosurgery further both in private and in government level after 2000.In 1997 the first MS (Neurosurgery) course was started in IPGMR which was replaced by a 5-year residency course under Bangabandhu Sheikh Mujib Medical University (BSMMU) in 2010. Till now over 154 candidates are the active members of Bangaldesh Society of Neurosurgeons and are practicing independent neurosurgery. It is a very popular course and at present there are about 89 residents in various phases of the course in 4 institutions under $B S M M U$. With the available investigations, diagnostic facilities, operative facilities and good neuroanesthesia; now neurosurgeons also developed their skills in vascular neurosurgery, pediatric neurosurgery, endoscopic neurosurgery, spinal stabilization procedures, stereotactic neurosurgery and stem cell therapy. We are also hopeful that, very soon we would be able to achieve and develop our standard of neurosurgery to an international level by our determination and continuous effort, and by suitable and update learning, teaching and training.
\end{abstract}

Key words: Neurosurgery, Bangladesh, BSMMU.

Bang. J Neurosurgery 2019; 8(2): 57-62

\section{Introduction:}

Bangladesh is a country in South Asia sharing its land border with India and Myanmar (Burma). The total area of the country is $147,570 \mathrm{~km}^{2}$. It became independent on $16^{\text {th }}$ December, 1971 from Pakistan by liberation war. Agriculture is the largest sector of the economy, making up 18.6 percent of Bangladesh's Gross Domestic Product (GDP) in November 2010 and employing about 45 percent of the workforce. It is one of the largest textile exporters in the world. Estimates of the Bangladeshi population vary, but 2016 UN data suggests 163 million. Bangladesh is

1. Prof. Akhlaque Hossain Khan, Professor and Course Coordinator, Department of Neurosurgery, Bangabandhu Sheikh Mujib Medical University, Dhaka-1000, Bangladesh.

2. Prof. A.T.M. Mosharef Hossain, Professor and Chairman, Department of Neurosurgery, Bangabandhu Sheikh Mujib Medical University, Dhaka-1000, Bangladesh.

3. Dr. Narendra Shalike, MS Neurosurgery, Department of Neurosurgery, Bangabandhu Sheikh Mujib Medical University, Dhaka-1000, Bangladesh.

4. Prof. Kanak Kanti Barua, Professor and Former Chairman, Department of Neurosurgery, Bangabandhu Sheikh Mujib Medical University, Dhaka-1000, Bangladesh.

Address of Correspondence: Prof. Akhlaque Hossain Khan, Professor and Course Coordinator, Department of Neurosurgery, Bangabandhu Sheikh Mujib Medical University, Dhaka-1000, Bangladesh. Email: akhlaque63neuro@yahoo.com Cell No.: $+880-1711471153$ the world's eighth most populous country. The per capita income of the country as of 2018 estimate is $\$ 4,561$. The country has a low literacy rate, which was estimated at 66.5 percent for males and 63.1 percent for females in 2014. Health and education levels remain relatively low, although they have improved as poverty levels have decreased. ${ }^{1}$

Bangladesh has an average life expectancy of approximately 70 years. The chances of dying between the ages of 15 and 60 years are more than 1 in 4 . Health remains an important goal and instrument of development in this ever-growing nation. The beginning of neurosurgery is not very new in Bangladesh. ${ }^{2}$

During the Pakistan period Professor Omar ValiJooma (AKA Jooma Khan) used to come from Karachi to provide consultancy primarily for head injury patients. It was a very limited and expensive facility. ${ }^{3}$

Professor Rashiduddin Ahmad (1937 2016)returned to East Pakistan in 1970 after having completed his Fellowship of the Royal Colleges of Surgeons (FRCS) \& five years Neurosurgery training under Professor F. John Gillingham in Edinburg and established the first Neurosurgery unit in the then Institute of Postgraduate Medical Research(IPGMR) (now Bangabandhu Sheikh Mujib Medical University- 
BSMMU) with only six beds. He took part in the liberation war and went back to UK for fear of his life. He again joined in 1976 in the Department of Neurosurgery, IPGMR. He is considered to be the Founder of Neurosurgery of Bangladesh. . $^{3,4}$

Professor A H M Ahsanullah (1937-2014), a neurosurgeon that time, started Neurosurgery in IPGMR in 1972 in independent Bangladesh.Professor Ata Alahi Khan (1939-2016) started Neurosurgery in Dhaka Medical College Hospital(DMCH) in 1975. Professor Lutful Anwar Quaderystarted Neurosurgery in Chittagong Medical College Hospital $(\mathrm{CMCH})$ in 1978. They were the first generation neurosurgeons of Bangladesh. 3,5

The first generation neurosurgeons left the field of neurosurgery in the safe hands of their disciples, notably Prof. Mohammad Afzal Hossain, Prof. Kanak Kanti Barua, Prof. Shafique Uddin Ahamed, Prof. Waheed Uz Zaman, Brig. Gen. Mohammad Nuruzzaman, Prof. Nausher Alam, Prof. Abul Khair and others. Since then they had been working hard together to establish neurosurgical centres all over the country to increase the number of beds in neurosurgery wards, and to motivate, inspire and train new doctors to consider neurosurgery as career path.

\section{Methods and Materials:}

This retrospective study has reviewed the computer database with details of neurosurgeons from Department of Neurosurgery of BSMMU, DMCH, National Institute of Neurosciences and Hospital (NINS), $\mathrm{CMCH}$ and Bangladesh Society of Neurosurgeons (BSNS), Dhaka, Bangladesh from January 2017 to September 2018. The data regarding the total no. of neurosurgeons in Bangladesh, total no. of female neurosurgeons in Bangladesh (graduated and currently undergoing residency program), total no. of current residents in four of the colleges/institute under BSMMU, foreign students with MS Neurosurgery course from BSMMU, and bed distribution and statistics of the patients in four of the above mentioned institutes are compiled and analyzed.

\section{Results:}

From the establishment of Neurosurgery unit in then IPGMR in 1970 to June 2018, about 154 neurosurgeons are documented as members of Bangladesh Society of Neurosurgeons. Following year 2000 , there was a rapid progression of in the field ofneurosurgery further both in private and in government level. At the same time post-graduation courses also expanded much more ever than the past.
About 68 (44.2\%) neurosurgeons graduated with Master in Surgery (MS) Neurosurgery non-residency and non-residency course and Fellowship of College of Physicians and Surgeons (FCPS) Neurosurgery course from 2010-2018 and 61 (39.6\%) neurosurgeons graduated at the first decade of 2000 while there was only 4 first generation neurosurgeons in the 70s decade (Fig. 1 and Table 1).

Currently we have approximately 1 neurosurgeon per million population of Bangladesh (Table 1). As pipeline neurosurgeons, 89 residents are expected to be graduated from four of the institutions with MS residency course under BSMMU from 2019-2023 (Table 2).

It was observed that, till now out of 154 members of BSNS, only $4(2.6 \%)$ female neurosurgeons have been graduated and $6(4.5 \%)$ out of 89 residents are currently in MS residency course under BSMMU.

From 2002 to 2018, 13 foreign residents (all Nepalese) have been graduated with MS Neurosurgery Nonresidency and Residency course from BSMMU and currently there are 7 foreign residents ( 6 from Nepal and 1 from Bhutan) undergoing MS residency course at BSMMU (Table 3).

Among four of the institutions currently with MS Neurosurgery residency course, $\mathrm{DMCH}$ has majority of beds distributed for neurosurgical patient (290 beds) followed by NINS with 175 beds, BSMMU with 95 beds and $\mathrm{CMCH}$ with 88 beds excluding cabin bed facilities (Table 4).

\section{Table-I}

Total No. of Neurosurgeons in Bangladesh per total population ${ }^{8,9}$

\begin{tabular}{lcc}
\hline $\begin{array}{l}\text { Year } \\
\text { (in decades) }\end{array}$ & $\begin{array}{c}\text { No. of } \\
\text { Neurosurgeons } \\
\text { in Bangladesh }\end{array}$ & $\begin{array}{c}\text { Population } \\
\text { (in millions) }\end{array}$ \\
\hline $1970-1979$ & $* 4$ & $70-80$ \\
$1980-1989$ & 9 & $80-105$ \\
$1990-1999$ & 12 & $105-130$ \\
$2000-2009$ & 61 & $130-150$ \\
$2010-2018$ & 68 & 160 \\
Total & 154 & \\
1 neurosurgeon per 1 million population (approximate) & Pipeline & 180 \\
\multicolumn{4}{c}{ (estimated) } \\
2019-2023 & (Expected) & \\
1 neurosurgeon per 750,000 population (approximate)
\end{tabular}

*Note: Out of 4 first generation neurosurgeons (1970-79), only one is alive now. 


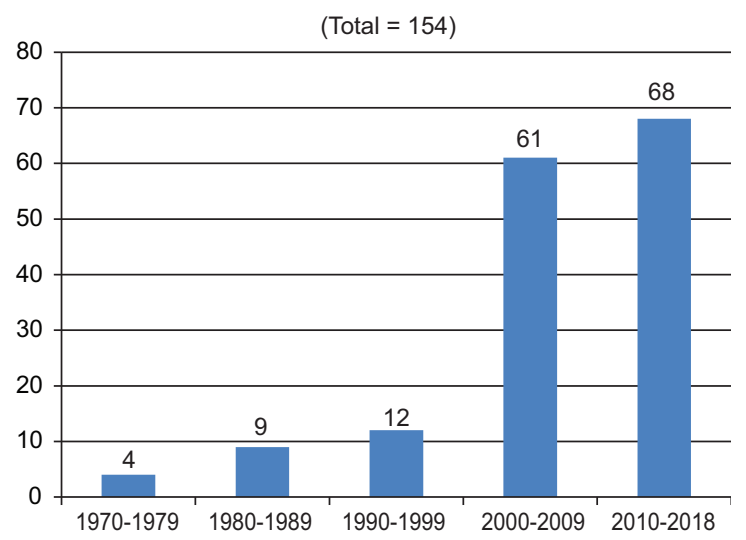

Fig.-1: Total No. of Neurosurgeons in Bangladesh ${ }^{8,9}$

Table-II

Total No. Current Residents in various institutes/medical colleges of Bangladesh ${ }^{7}$

\begin{tabular}{lccccc}
\hline Session year & BSMMU & DMCH & NINS & CMCH & Total residents \\
\hline 2011 & 1 & & & & \\
2012 & 2 & & & & \\
2013 & 4 & & & 3 & 89 \\
2014 & 7 & 6 & & 3 & (on pipeline \\
2015 & 7 & 6 & 5 & 3 & \\
2016 & 5 & 6 & 5 & 3 & \\
2017 & 6 & 6 & 10 & 15 & \\
2018 & 8 & 24 & & & \\
\hline Total & 40 & & & &
\end{tabular}

Table-III

Foreign students with MS Neurosurgery course from BSMMU (From Nepal and Bhutan) ${ }^{7,9}$

\begin{tabular}{llc}
\hline Year & Name of the Neurosurgeons & Total \\
\hline $2002-2011$ & $\begin{array}{l}\text { Graduated from BSMMU } \\
\text { (Non-residency course) }\end{array}$ & 4 \\
$2011-2018$ & $\begin{array}{l}\text { Graduated from BSMMU } \\
\text { (Residency course) }\end{array}$ & 9 \\
$2019-2023$ & \begin{tabular}{l} 
Pipeline Neurosurgeons (Expected) \\
\hline
\end{tabular}
\end{tabular}

Table-IV

Bed distribution at Department of Neurosurgery of various instituitions ${ }^{10}$

\begin{tabular}{|c|c|c|c|c|c|c|c|c|}
\hline \multirow[t]{2}{*}{ Ward } & \multicolumn{2}{|c|}{ BSMMU } & \multicolumn{2}{|c|}{$\mathrm{DMCH}$} & \multicolumn{2}{|c|}{ NINS } & \multicolumn{2}{|c|}{$\mathrm{CMCH}$} \\
\hline & Bed & Total & Bed & Total & Bed & Total & Bed & Total \\
\hline Male ward & 38 & 95 & 140 & 290 & 80 & 175 & 35 & 95 \\
\hline Female Ward & 29 & & 110 & & 67 & & 30 & \\
\hline Emergency Ward & 28 & & 40 & & 28 & & 30 & \\
\hline
\end{tabular}


Table-V

Statistics of patients in Department of Neurosurgery ${ }^{10}$

\begin{tabular}{|c|c|c|c|c|c|c|c|c|c|c|}
\hline \multirow{2}{*}{\multicolumn{3}{|c|}{ Criteria }} & \multicolumn{8}{|c|}{ No of patients per year } \\
\hline & & & \multicolumn{2}{|c|}{ BSMMU } & \multicolumn{2}{|c|}{$\mathrm{DMCH}$} & \multicolumn{2}{|c|}{ NINS } & \multicolumn{2}{|c|}{$\mathrm{CMCH}$} \\
\hline \multicolumn{3}{|c|}{ Indoor patients' admission } & \multicolumn{2}{|c|}{$800-1000$} & \multicolumn{2}{|c|}{$10,000-11,000$} & \multicolumn{2}{|c|}{$2,000-2,500$} & \multicolumn{2}{|c|}{$\begin{array}{l}9000- \\
10,000\end{array}$} \\
\hline \multicolumn{3}{|c|}{ Emergency patients' admission } & \multicolumn{2}{|c|}{$300-400$} & \multicolumn{2}{|c|}{$2,000-2,500$} & \multicolumn{2}{|c|}{$500-600$} & \multicolumn{2}{|c|}{$\begin{array}{l}8,000- \\
8.500\end{array}$} \\
\hline \multicolumn{3}{|c|}{ Outdoor patients check up } & \multicolumn{2}{|c|}{$\begin{array}{c}15,000- \\
16,000\end{array}$} & \multicolumn{2}{|c|}{$16,000-17,000$} & \multicolumn{2}{|c|}{$15,000-16,000$} & \multicolumn{2}{|c|}{$\begin{array}{l}6,000- \\
7,000\end{array}$} \\
\hline \multirow{3}{*}{$\begin{array}{l}\text { Neurosurgery } \\
\text { performed }\end{array}$} & \multirow{2}{*}{$\begin{array}{l}\text { Elective } \\
\text { surgery }\end{array}$} & $\begin{array}{l}\text { Cranial } \\
\text { surgery }\end{array}$ & $\begin{array}{l}450- \\
550\end{array}$ & \multirow{2}{*}{$\begin{array}{l}800- \\
1000\end{array}$} & $\begin{array}{l}3,500- \\
4,000\end{array}$ & \multirow{2}{*}{$\begin{array}{l}5,500- \\
6,500\end{array}$} & $\begin{array}{l}1,100- \\
1,200\end{array}$ & $1,800-$ & $\begin{array}{l}350- \\
400\end{array}$ & \multirow{2}{*}{$\begin{array}{l}550- \\
650\end{array}$} \\
\hline & & $\begin{array}{l}\text { Spinal } \\
\text { surgery }\end{array}$ & $\begin{array}{l}350- \\
450\end{array}$ & & $\begin{array}{l}2,000- \\
2,500\end{array}$ & & $\begin{array}{l}700- \\
800\end{array}$ & 2,000 & $\begin{array}{l}200- \\
250\end{array}$ & \\
\hline & \multicolumn{2}{|c|}{ Emergency surgery } & \multicolumn{2}{|c|}{$150-250$} & \multicolumn{2}{|c|}{$2,000-2,200$} & \multicolumn{2}{|c|}{$400-500$} & \multicolumn{2}{|c|}{$\begin{array}{l}8,000- \\
8,500\end{array}$} \\
\hline
\end{tabular}

\section{Discussion:}

Bangabandhu Sheikh Mujib Medical University is the premier Postgraduate Medical Institution of the country established on $30^{\text {th }}$ April 1998. It bears the heritage to IPGMR which is the first neurosurgical centre in the country with emergency neurosurgical services. In 1997 the first MS (Neurosurgery) course was started in IPGMR. It was a 3-year academic course under the University of Dhaka. Similar courses were started at Dhaka Medical College also in 1997 and at Chittagong Medical College in 2002. ${ }^{6}$

Following year 2000 , there was a rapid progression of neurosurgery further both in private and in government level. Moreover, few of the neurosurgeons got long and short term training/fellowships in various sub-faculties of neurosurgery from other countries like UK, Turkey, India, Russia, Japan, Australia, Germany, Korea Republic, Singapore, USA and China. Of course, Japan has given tremendous support in all aspects of neurosurgery (training, fellowship, scholarship, seminar, workshop and instrumental support) for Bangladesh and young neurosurgeons are benefitted which helped to change the view of neurosurgery. ${ }^{6}$

At the same time post-graduation courses also expanded much more ever than the past. Hence the neurological facilities have been becoming more available for all income level persons like the richer and poorer. ${ }^{6}$

In 2010, this was replaced by a 5-year residency course under BSMMU. It is a very popular course and at present there are about 89 students in various phases of the course in 4 institutions. Some of the students are from neighboring country Nepal and Bhutan. Till now over 140 candidates have completed the MS course and are practicing independent neurosurgery. Among them, over 120 neurosurgeons are working in the government hospitals while over 25 neurosurgeons are serving in the private/corporate hospitals. The Bangladesh College of Physicians and Surgeons (BCPS) also offer FCPS (Neurosurgery), a neurosurgery fellowship. ${ }^{7}$

Bangladesh Society of Neurosurgeons is our prestigious society established in 1998. Prof. Rashiduddin Ahmed was the 1st President and Prof. KanakKantiBarua was General Secretary of the society. Neurospine Society of Bangladesh was established in 2015. We are the Founder member of Asian Congress of Neurological Surgeons (1993), South Asian Association of Neurosurgeons (1999) and member of World Federation of Neurosurgical Societies (2000). ${ }^{7}$

The Bangladesh Society of Neurosurgeons, which has 154 active members today, had hosted the South Asian Neurosurgical Conference (SANC) meetings twice in 2001 and in 2015. Under the auspices of these affiliations, various educational, cadaveric and live surgical workshops had been held in Bangladesh. Many young neurosurgeons have been afforded long and short term fellowship opportunities by these organizations. The first official Journal of the society, Bangladesh Journal of Neurosurgery was published in July $2011 .{ }^{7}$ 
Before 1987 the following investigations were available:Plain X-rays, Isotope Brain Scan, Cerebral Angiography (Direct Puncture), Burrhole Ventriculography, Lumber Air Encephalography, Myelography, Orbital Phlebography. Before the availability of Computed tomography (CT), Magnetic Resonance Imaging (MRI)\&Digital Subtraction Angiography (DSA), all the above gave indirect evidence of cranial and spinal pathologies. ${ }^{6}$

In 1987 CT and in 1996 MRI became available. The first CT scanner was a second generation machine at BIRDEM and the first MRI scanner was a 0.3 Tesla machine at the Holy Family Red Crescent Hospital.Subsequently further advanced CT and MRI machines became available.CT: Angiography, 3D reconstruction of bones, MRI: Angiography, Magnetic resonance spectroscopy (MRS), Magnetic resonancetractography, Diffusion tensor imaging(DTI), Positron emission tomography (PET), Single-photon emission computed tomography (SPECT), DSA, Duplex Study for neck vessels and Transcranial Doppler, CT and MRI scanners are widely available throughout the country sometimes even at district levels. ${ }^{6}$

With the available investigations, diagnostic facilities, operative facilities and good neuroanesthesia; now Neurosurgeons also developed their skills in vascular neurosurgery, pediatric neurosurgery, endoscopic neurosurgery, spinal stabilization procedures, stereotactic neurosurgery and stem cell therapy.

The interventional neurosurgery is a new wing dealing with cerebral and spinal vascular diseases. The first neurointerventional surgery was performed under the guidance of Prof. Rashiduddin Ahmed in 1979 by direct carotid puncture.

\section{Advancement in the availability of neurosurgical services 6,8}

Today, neurosurgical services are widely available throughout the country. These include:

- Bangabandhu Sheikh Mujib Medical University started from 1970

- Dhaka Medical College \& Hospital - from 1975

- Chittagong Medical College \& Hospital - from 1978

- National Institute of Neurosciences and Hospital established on $12^{\text {th }}$ November 2012.

- Combined Millitary Hospital - since 1987
- Sir Salimullah Medical College \& Mitford Hospital 1994.

- Mymensingh Medical College \& Hospital - 1997.

- Sylhet M A G Osmani Medical College \& Hospital 1996.

- Rajshahi Medical College \& Hospital - 1991.

- Rangpur Medical College \& Hospital - July 2007.

- Comilla Medical College \& Hospital - 2012

- Sher E Bangla Medical College \& Hospital - 1992.

- Dinajpur Medical College \& Hospital - 2012.

- Shaheed Sheikh Abu Naser Specialized Hospital, Khulna - 2012.

- Shaheed Ziaur Rahman Medical College, Bogra 2010.

- Faridpur Medical College - 2012

There are many well equipped neurosurgical facilities in the private sector spread all over the country.

It should be stressed, however, that most of the Bangladeshi population, especially in rural areas, still does not have access to effective neurosurgical services. The number of neurosurgeons in Bangladesh is inadequate, and in number different areas of the country an imbalance exists with regard to the availability of neurosurgeons. In the future, it will be necessary to train many younger doctors in neurosurgical practice by sending them not only to foreign countries to gain advanced skills but also to rural areas for further practical experience. ${ }^{11}$

Neurosurgery faces many future challenges. The development and acquisition of new technology naturally leads to higher costs. Already, these issues are evident in cases where the state of the art dictates multimodal therapy while patients must choose between, for example, radiosurgery and microsurgery. Furthermore, postoperative follow-up of large numbers of patients can be difficult, making problematic the translation of clinical experience into clinical research. Resource availability issues will become even direr as continued economic development of our country increases the population's standard of living and further elevates the public's expectations.Despite these challenges, the evolution of neurosurgery in Bangladesh from the recent past to its current status is indeed encouraging. It has begun to develop, and it will advance further in future. ${ }^{12}$ 


\section{Conclusion:}

A dedicated soul is needed to become a good neurosurgeon. We are hopeful that, very soon we would be able to achieve and develop our standard of neurosurgery to an international level by our determination and continuous effort, and by suitable and update learning, teaching and training.

\section{Acknowledgement:}

We are very much grateful to Prof. M. AfzalHossain, Former Chairman, Department of Neurosurgery, BSMMU, to Prof. Asit Chandra Sarker, Chairman, Department of Neurosugery, DMCH, to Prof. Sk. Sader Hossain, Chairman, Department of Neurosurgery, NINS, and to Prof. Noman Khaled Chowdhury, Department of Neurosurgery, $\mathrm{CMCH}$ for their continuous guidance and support in preparing this article.

\section{Reference:}

1. Wikipedia. Bangladesh. Available from: https:// en.wikipedia.org/wiki/Bangladesh [Accessed $4^{\text {th }}$ September 2018].

2. Alam S, Khari A. The development of neurosurgery in Bangladesh. Orion Medical Journal 2010 May;33(2):738.
3. Hossain SS. Neurosurgery in Bangladesh: Past, Present and Future. Journal of National Institute of Neurosciences Bangladesh. 2016 Jul;2(2):46-7.

4. Khan AH. Life sketch of Prof. Rashiduddin Ahmed. [Lecture] Bangabandhu Sheikh Mujib Medical University. $18^{\text {th }}$ March 2018.

5. Khan AH. Life sketch of Prof. AHM Ahsanullah. [Lecture] Bangabandhu Sheikh Mujib Medical University. $12^{\text {th }}$ February 2018.

6. Hossain MA. History of Neurosurgery. [Lecture] Oxford University. $12^{\text {th }}$ October 2017.

7. Barua KK. History of Neurosurgery in Bangladesh. [Lecture] Bangabandhu Sheikh Mujib Medical University. $1^{\text {st }}$ March 2018.

8. Bangladesh Society of Neurosurgeons. Voter List. 2018.

9. Office of Controller of Examination. List of Neurosurgeons graduated from BSMMU. Bangabandhu Sheikh Mujib Medical University 2018.

10. Barua KK, Hossain ATMM, Khan AH. Self-assessment report 2017. Institutional Quality Assurance Cell BSMMU 2018.

11. Masrur S. A Cross Sectional Study on The Type of Patients And Treatment Intervention in A Neurosurgery Department of A Tertiary Hospital in Bangladesh (Doctoral dissertation, East West University).

12. Rahman ML. Recent trends in Neurosurgery and Bangladesh perspective. TAJ: Journal of Teachers Association. 2001;14(2):51-2. 